Chapter

[2]

\title{
A review on impact of water pollution on freshwater fish species and their aquatic environment
}

\author{
D.S. Malik ${ }^{1}$, Amit Kumar Sharma ${ }^{1,}$, , Arvind Kumar Sharma ${ }^{1}$, \\ Rishi Thakur ${ }^{2}$ and Munish Sharma ${ }^{2}$
}

${ }^{1}$ Aquatic Biodiversity Conservation Laboratory, Department of Zoology and Environmental Science, Gurukula Kangri (Deemed to be University), Haridwar 249404, Uttarakhand, India ${ }^{2}$ School of Life Sciences, Central University of Himachal Pradesh, TAB, Shahpur, Kangra, India

Abstract

Freshwater is a chief natural resource used for various types of activities in our daily life i.e. for drinking as well as different developmental purposes. An increase in pollution level leads to instability in our natural environment and harm both the physical systems and living organisms dwelling in the ecosystem. Various harmful substances present in polluted water bodies in the form of insecticide, pesticides, heavy metals, mills waste, and crude oil are frequently released into the aquatic ecosystem. When a large amount of these pollutants is released into any water body, causes an acute effect by rapid highscale mortalities of aquatic organisms. Minor levels of pollutant discharge result in an accumulation of the contaminants in the body composition of fish species. Water pollution effects are classified into acute and chronic effects, which suppress immune-response, reduction of metabolism, harm to gills, and epithelial layer in the fish species. Some of the diseases caused by the pollutant include fin rot, tail rot, gill disease, damage hepatic tissues, and also causes ulceration. This chapter aims to reviews the various types of impacts caused by water pollution on the health of fish species and their ecosystem.

Keywords Aquatic environment, Fish species, Toxicity, Wastewater, Water pollution

D. Amit Kumar Sharma, Email: rs.amit@gkv.ac.in ( ${ }^{*}$ Corresponding author)

(C) 2020 | Agro Environ Media I Agriculture and Environmental Science Academy, Haridwar, India 


\section{Introduction}

Water pollution happens when some unwanted constituents enter into the water bodies and change the water quality (Alrumman et al., 2016), and becomes harmful to human health and their environment (Briggs, 2003). Water plays an important role in nutrient recycling and is an imperative natural source used for drinking and other developmental purposes. Aquatic systems are usually used for disposal and reutilizing the sewage and contaminated wastes and drain off the excess to the sea. Due to the increase in the pollutant level and in turn overexploitation of the water resources for various developmental activities i.e. for agriculture, construction activities, industrial processes, and also in thermal power plants to encounter the necessities of the large-scale population, significantly lessens their assimilative volume. Thus, the double pressure wielded on the water bodies is eventually faced by the biological communities dwelling them.

Generally, the fish species are one of the most important aquatic communities concerning humans. The pollution generally denotes any unwanted alteration in the natural quality of any ecosystem brought around by the changes in their physical, chemical, as well as in biological factors (Subhendu, 2000). Aquatic ecosystems are delicate and at high risk mostly due to the majority of pollutants derived from domestic, urban and industrial sources i.e. various agricultural practices (Figure 1) result in the release of pollutants into the riverine system (Kaur and Dua, 2014; Pinto et al., 2015; Byrne et al., 2015). Mainly in aquatic ecosystem, the most frequent contaminants are in the forms of heavy metals and pesticides (Khoshnood, 2016). The heavy metals are one of the major pollutants, which quickly amass in the body and are leisurely digested in and excreted from aquatic animals. Mainly the pesticides used in agricultural activities are directly released into the open atmosphere by drift spray, volatilization and wind erosion of soil (Qiu et al., 2004). These pesticides present in aquatic ecosystem can affect the life cycle of aquatic organisms (Ventura et al., 2008).

Increases in the population rate resulted in an increase in the development and urbanization, water pollution by domestic activities, agronomic processes, the municipal and industrial processes have become a key concern for the wellbeing of humanity. Water-soluble pollutants released from different industries and municipal activities, leached in soils directly and in turn, the atmosphere has quickly transported to natural water bodies. Some of the toxins decay or volatilize to form insoluble salts and rest are precipitated and get combined into the substrate in bed surface. Fish species are the perfect model for sensing the occurrence of genotoxic toxins in aquatic ecosystems (Aich et al., 2015; Walia et al., 2015; Sharma et al., 2018) because these aquatic organisms are very sensitive to little quantity of metals within the water body, are abundant, and also live in some different habitats (Ali et al., 2008). Aquatic organisms like fish species directly uptake these toxic substances may be followed by the metabolism of these toxic substances which results in more toxic by-products. For example, mercury can be converted into very high toxic methyl-mercury by the microbial action which in turn taken up 


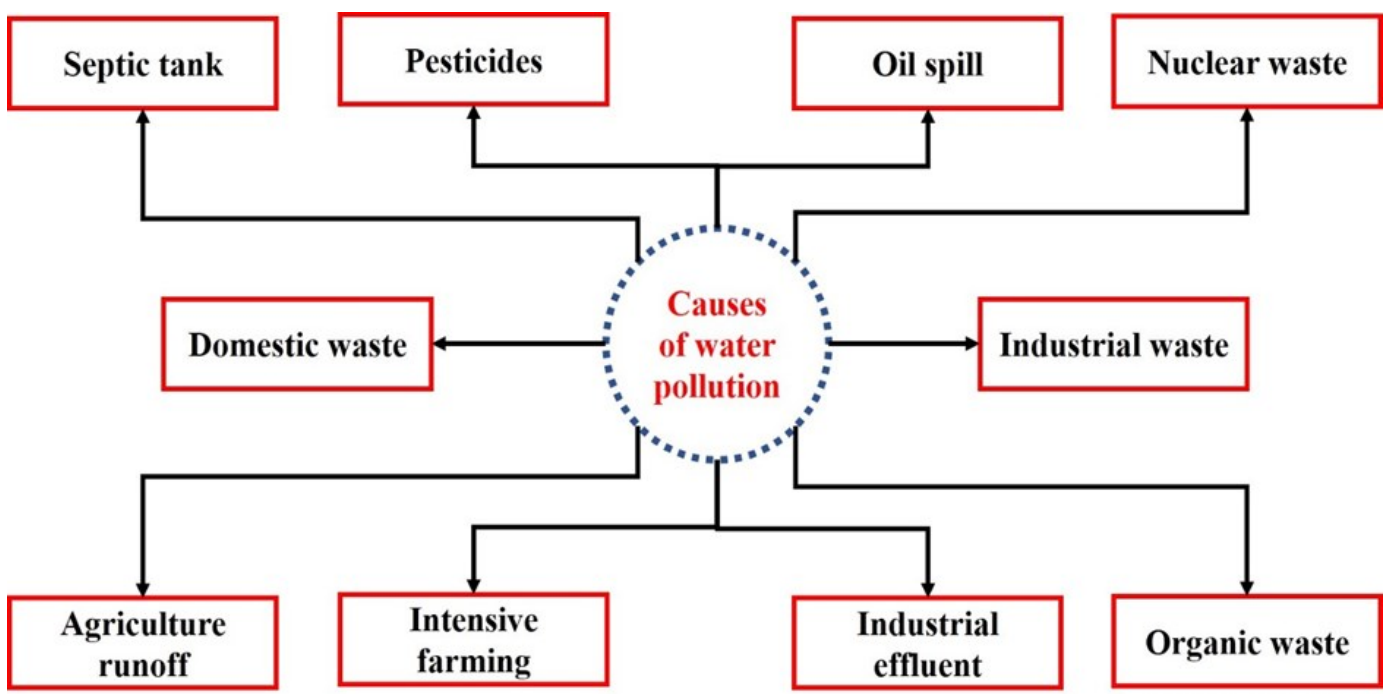

Figure 1. Different causes and sources of water pollution that affect aquatic life.

by fish species (Bukola et al., 2015). Fish fry, larvae, yearlings and fingerlings are one of the most susceptible life stages which are harshly affected by pesticides and heavy metal pollution exposure as non-target aquatic organisms. Alterations of the vital organs i.e. gills, kidney, and liver might distress the physiology, rate of survival, osmoregulation, buoyancy, reproduction processes etc., and in turn lead to failures in stock conscription and populace changes (Khoshnood, 2017).

Some aquatic animals have been identified to concentrate the toxic solutes from their habitat without any apparent harm to themselves and thus acts as pollutant amplifiers, making the toxic substances offered to predators at dangerously high levels. Some cases have been reported explaining the adverse impacts of environmental pollutants on fish's health and also to fish consumers. Due to the increased anthropogenic activities, a high load on the aquatic ecosystem determines the necessity of researches fervent to check the adverse impacts of water pollution and its probable risk for the aquatic organism and their ecosystems. Different types of lethal impacts of water pollution have been perceived in aquatic communities inhabiting the water bodies over numerous scientific researches. The decreasing fish populaces and partial loss of commercial fishing predict huge changes in the aquatic ecosystem (Hinton and Lauren, 1990).

Fish communities are one of the most valued resources of high mark protein to humans. The modifications in the morphology, tissue and biochemical composition by the aquatic organism highlight the different types of stress and changes in habitat ecosystem e.g. if some fish species are exposed to chemical contaminants, acts rapidly and induces a series of modifications in different body parts and organs, mostly gills, kidneys and liver (Bukola et al., 2015). Thus, a varied series of 


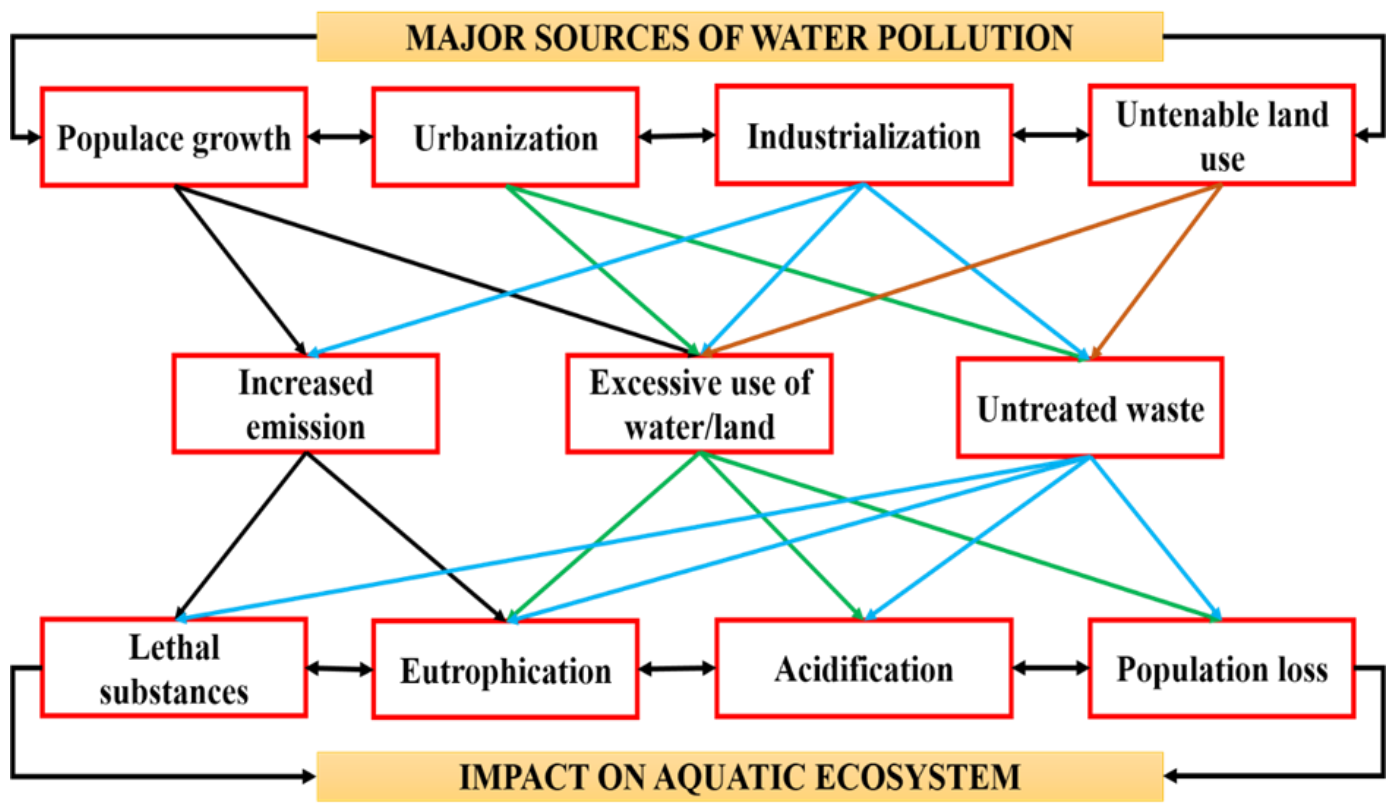

Figure 2. Impact of water pollution on aquatic ecosystem.

histo-cytological changes in fish species have been developed and endorsed as biomarkers for the purpose of monitoring the water pollution level. Several factors (Figure 2) like increasing population, industrialization, urbanization, forest loss, lack of environmental awareness among society, lack of policy implementation, rules and regulations, effluent discharge from different industries, etc leads to pollution in the aquatic ecosystem and ultimate loss of aquatic organisms.

The pollutants released from different types of industrial discharge and sewage not only pollute the surface water of rivers and reservoirs but also infiltrate into ground and also pollute the groundwater resources. Aquatic ecosystems are exposed to pollution loads is associated with the increase in urbanization and population growth (Edokpayi and Nkwoji, 2000; Nkwoji et al., 2010). These pollutants cause major threats to aquatic ecosystems, alter hydrology, physicochemical and faunal characteristics (Nkwoji et al., 2010). Nowadays, the most perilous difficulties of developing nations are unsuitable management of massive quantity of wastes material produced by numerous anthropogenic activities. Among them, the most challenging factor is the unsafe disposal of these effluents into the open ambient environment. From these activities the water bodies particularly, freshwater bodies like rivers and reservoirs are most affected and unfit these types of natural resources for both primary and secondary usage. Thus, the aim of this review paper mainly deals with the impact assessment of water pollution on fish health and their habitat. 


\section{Sources of water pollutants}

Mainly water pollution derives from two extensive sources i.e. point sources and non-point sources (Figure 3). Point sources are the identified type of pollutants sources where all the pollutant materials enter into water bodies from a single recognizable source i.e. ultimate effluent discharge point of different industrial outfit wherein non- point source, the pollutant substances come in the contact water bodies in numerous and not easily recognizable sources. Almost all hominid actions have the potential to impact directly or indirectly the surface and groundwater quality of any water bodies e.g. fertilizers used by agriculturalists in the agricultural activities are steadily eroded by rain into the surface and groundwater nearby thus pollutes the water body.

Human and developmental activities e.g. effluents from industries, irrigation activities, waste managing problems, and also rise in urbanization possessed some serious threats to the freshwater ecosystem (Zhu et al., 2018; Meijide et al., 2018; Kamboj et al., 2020). Climatic variation also possesses an impact on both biotic and abiotic characteristics i.e. water as well as air temperature and rainfall levels affect the regular function of any aquatic ecosystems including feeding and breeding of aquatic organisms (Figure 4).

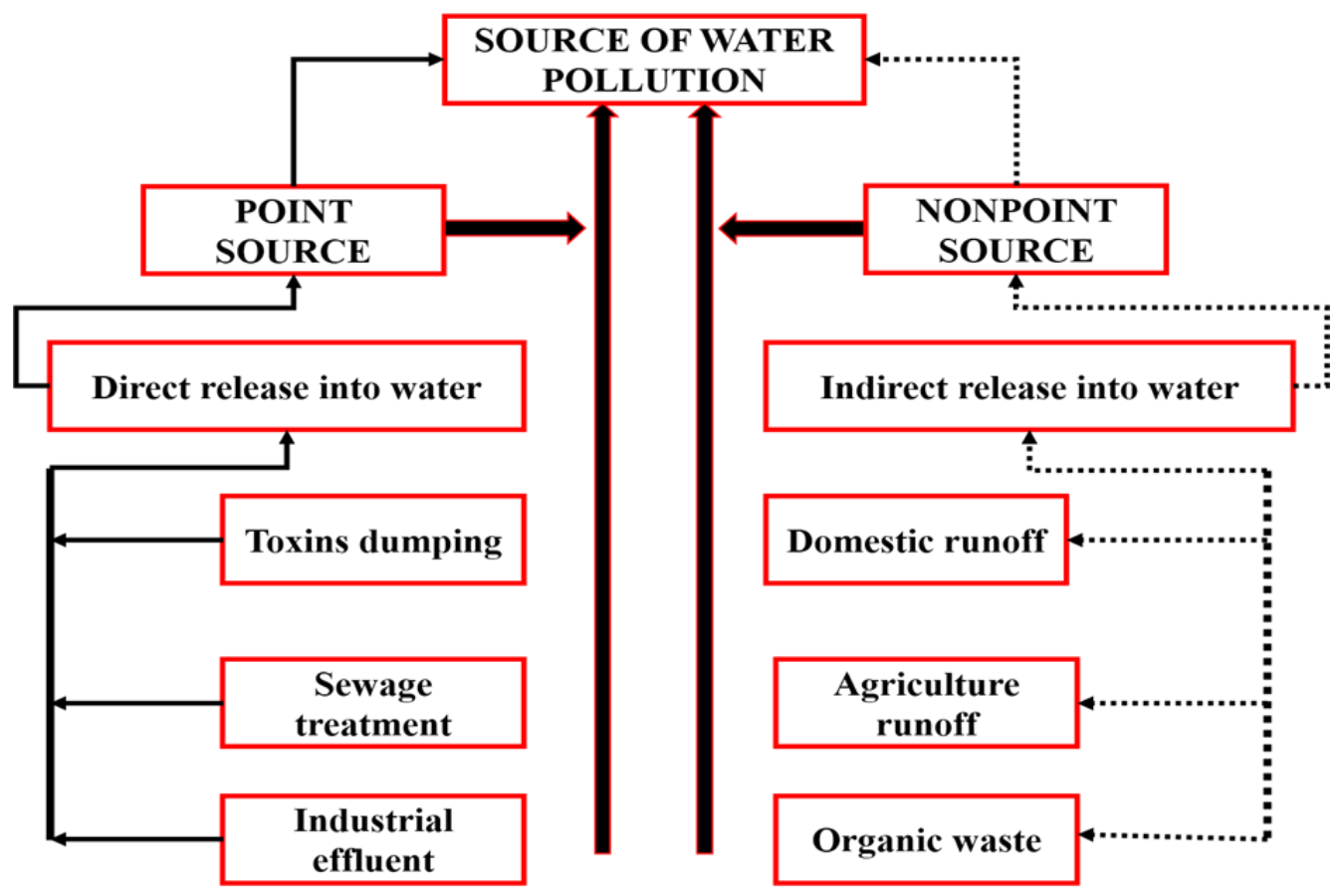

Figure 3. Point and non-point sources of water pollution. 


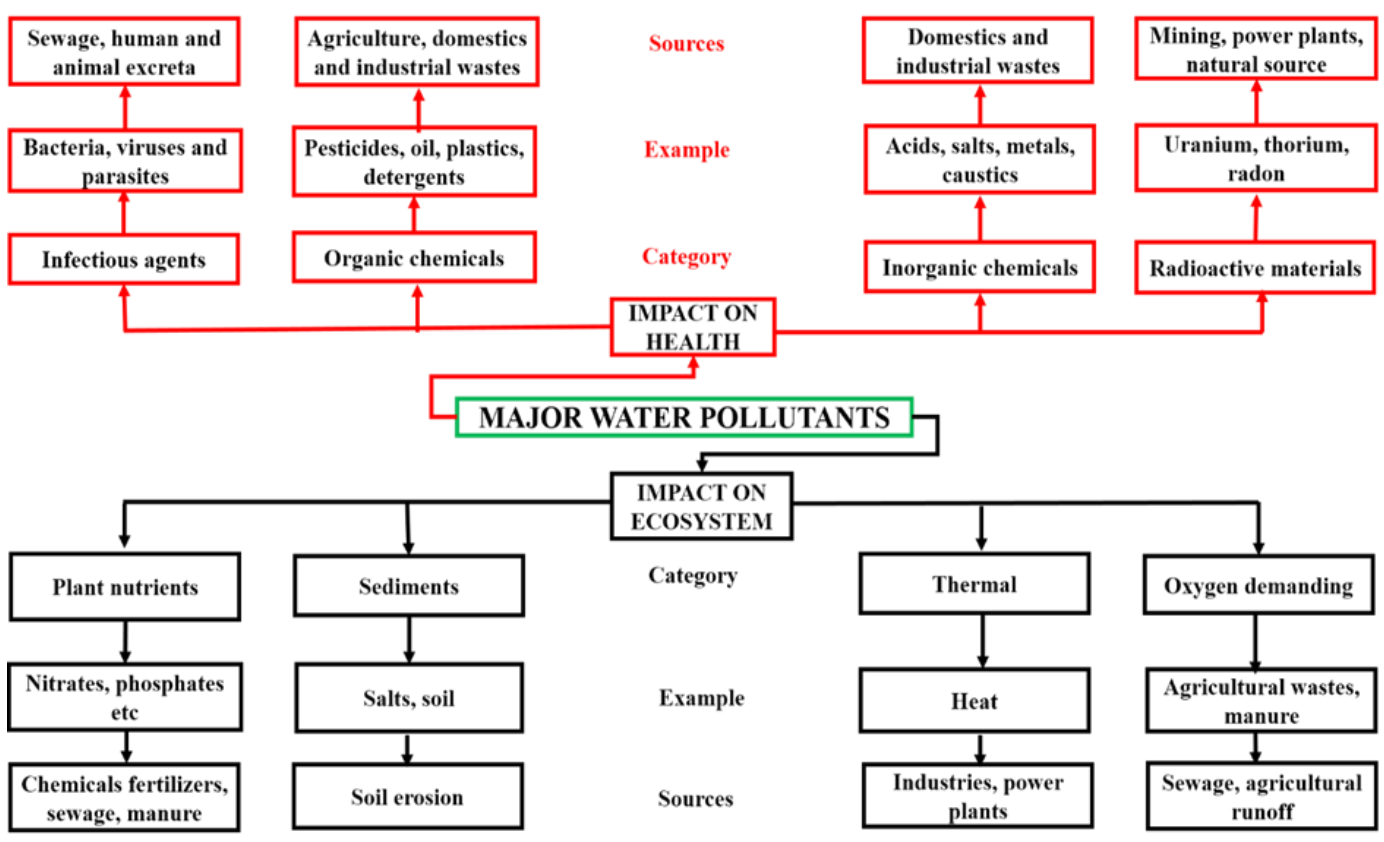

Figure 4. Major pollutants along with their source.

Table 1. Inorganic and organic pollutants from different industries.

\begin{tabular}{lll}
\hline Industry & Inorganic pollutants & Organic pollutants \\
\hline Mining Industry & $\begin{array}{l}\text { Chlorides, ferrous sulphate, hydrogen } \\
\text { sulphide. ferric hydroxide, suspended } \\
\text { solids and heavy metals. } \\
\text { Steel/Iron Industry } \\
\text { Suspended solids, iron cyanide, sulphides, } \\
\text { oxides, of copper. chromium, cadmium, } \\
\text { and mercury } \\
\text { Sulphates, nitrates, phosphorus, fluorine, } \\
\text { silica, and suspended particles }\end{array}$ & $\begin{array}{l}\text { Oil, phenol and naptha } \\
\text { Pharma Industry }\end{array}$ \\
- & $\begin{array}{l}\text { Arganic acids, nitro compound } \\
\text { dyes, etc. } \\
\text { Proteins, carbohydrates, organic } \\
\text { solvents, intermediate Products, } \\
\text { drugs and antibiotics }\end{array}$ \\
Detergent Industry & Tertiary ammonia compounds, alkalies & $\begin{array}{l}\text { Fats and fatty acids, glycerol, } \\
\text { polyphosphates sulphonated } \\
\text { hydrocarbons } \\
\text { Cellulose fibres, bark, wood, } \\
\text { sugars and organic acids }\end{array}$ \\
\hline
\end{tabular}

Source: Sonali Priyadarshi (nd) 
Also, these contamination levels affect the habitats of aquatic flora and fauna (Schmeller et al., 2018). Therefore, for conservation purposes, it is important to guard worldwide freshwater aquatic species and also safeguard the regular functions of ecosystems. Thus, it is very crucial to identify and classify the key pollution activities, sources, and fate in the aquatic ecosystem including their temporal and spatial distribution (Liu et al., 2018; Zhao et al., 2018). Considerate the influence of natural processes may support in developing conservation curricula and policies to avoid the disturbance of freshwater ecosystem (Schmeller et al., 2018). The category of major water pollutants along with sources and example are given in flowchart (Figure 4).

\section{Impact of pollutants on the water quality}

Subhendu (2000) and Farkas et al. (2000) have reported several effects of pollution on physico-chemical properties of water.

Light: High turbidity and colour variations of the water bodies reduced the penetration quantity of light.

Fluctuations in temperature: The temperature of water increased during the thermal pollution where water is used for cooling power stations and also waste heat from industries.

Depth and flow: Both flow and depth of the water body reduced due to heavy siltation of sediments coming from land erosion.

pH: Acidic water due to acid rain or by burning of coal and oil fluctuates the $\mathrm{pH}$ of the water body. Large quantities of acids are originating from mines and many industrial processes like waste generated from DDT factory, from battery, tanneries and by vinegar etc. it is well reported that large scale of fish species habitually live between 6.0 and $9.0 \mathrm{pH}$ levels, although they cannot bear a rapid variation within this range

Dissolved oxygen: Due to the discharged of heavy sewage pollution and effluents containing high organic matter into any water body reduced greater amount of dissolve oxygen level. DO are also broken down by the physiological activity of microorganisms by using dissolved $\mathrm{O}_{2}$.

$\mathrm{CO}_{2}$ : Due to the eutrophication and organic pollutants dissolve oxygen depletes from water body with an increase in the $\mathrm{CO}_{2}$ level, due to decomposition of undecomposed organic matter.

Alkalinity: Wastes released from tanning, wool scouring, the mercerizing of cotton and the manufacture of certain chemicals industries (especially in chloro-alkali industries) contain caustic soda, sodium carbonate or lime. These alkaline effluents have $\mathrm{pH}$ range between 12-14, which becomes lethal to all types of aquatic life.

Salinity: Salinity reduces dissolve oxygen level by increase in excessive amount of salts transported from sewage, effluents and chloro-alkali industries, which increase the level of chloride and thereby salinity of water, which is further responsible for increasing the osmotic pressure. 
Colour and turbidity: Colour of water also changed due to the fluctuation in dye, pigment and turbidity of water. Turbidity increased from soil erosion or heavy algal bloom due to high load of organic and inorganic nutrients from both industries or agricultural waste.

Nitrates and phosphates: Water runoff by the agricultural wastes, soil erosion and organic pollutants i.e. from sewage and synthetic detergents) are rich in nitrates and phosphates quantity.

Heavy metals: In natural water, various trace elements are present in very small and trace amount like $\mathrm{Hg}, \mathrm{Ni}, \mathrm{Zn}, \mathrm{Cd}, \mathrm{Mn}, \mathrm{Pb}, \mathrm{Cu}, \mathrm{Cr}, \mathrm{Fe}$, As, Se etc. Increase in the quantity of the heavy metal can change the water quality e.g. exposure cadmium caused anaemia, discolouration of the teeth, damage to the olfactory nerve, ulceration of the nasal septum, rhinitis, and anosmia to the aquatic organism (Maurya et al., 2019).

Eutrophication: The eutrophication also effects directly or indirectly to the water quality. Water pollution from domestic sewage increases the organic load and also pollution from agricultural runoff containing huge amounts of nutrients such as potassium, nitrates; phosphates, etc. fertilize the water in and raise the rate of productivity of the aquatic ecosystem.

This process results in the complex growth of phytoplankton. Water becomes turbid due to the extreme growth of phytoplankton and suspended particles by soil erosion.

\section{Impacts on aquatic biota}

Instantly after organic pollution comes in contact with water bodies results in a decrease or even purging of algae due to de-oxygenation and little amount of light present. Further, this is followed by a gradual increase in algae abundance once situations improve. This gradual increase is stirred by the bulky concentrations of nutrients that are probable to be present (Mason, 1991). Planktons (phytoplankton and zooplankton), macrobenthos, fish species, and macrophytes are badly affected by biodegradable organic pollution (Hynes, 1960; Malik et al., 2018; Kumar et al., 2018). Generally, De-oxygenation decreases the light levels, increases TSS and settling material thus results in the reduction or loss of aquatic species which are most sensitive to the pollution (Hawkes, 1962; Haslam, 1987). Mainly in the downstream regions of rivers tends to be more of a problematic from biodegradable organic pollution (Mason, 1991).

This causes certain glitches for migratory fish species with high DO requirements i.e. in the case of Salmo salar and Salmo trutta. In a few cases, the levels of DO and organic pollutants can prompt avoidance behavior and acts as a barrier which averts them reaching highly oxygenated breeding and spawning grounds (Richardson et al., 2001).

\section{Impact of water pollution on algae and macrophytes}

Macrophytes are types of aquatic plants that grow in water and are classified either as emergent, 
floating, or submerged. Macrophytes act as bioindicator because they quickly respond to the rate and variability of many environmental characteristics i.e. water flow, alkalinity, substrate, shading, and nutrient concentrations (Barendregt and Bio, 2003; Lacoul and Freedman, 2006). Total suspended sediment adversely impacts the algae and aquatic macrophytes over limiting the quantity of light penetrating over the water column, which afterward limits the frequency of photosynthesis. A high quantity of suspended solids is commonly transported by the fast-flowing rates also scrub algae and aquatic macrophytes away from bed substrates which result in damage to their photosynthetic structures (Steinman and McIntire, 1990).

The process of sedimentation can be smothering the submerged flora which extremely reduces the rate of photosynthesis. Certain plants grow especially in water having low dissolved nutrients and high DO whereas other plants grow fine in nutrient-enriched water. This made it probable to rank and score aquatic macrophytes according to their preference for various chemical and physical conditions (Haury et al., 2002). Apart from that, the macrophytes are reasonably tolerant of erratic pollution and sturdily inclined by geology and soil type (Mason, 1991). Also, the macrophyte community structure is frequently resolute by some interconnected aspects which can make assigning species absence/presence to specific pollutants difficult (Pentecost et al., 2009). Macrophytes play an important role as bioindicator of chronic pollution problems in any water bodies.

\section{Impacts on macrobenthos}

Macrobenthos are aquatic animals that lack an internal skeleton, visible to the naked eye and inhabitant to bed substrate of water bodies. The bottom-dwelling organisms mostly comprise of larvae, pupae of insects, crustaceans, annelids, worms and molluscs. Macrobenthos are excellent indicators of water quality and pollution load due to some factors including (Malik et al., 2020):

- Macrobenthos are widespread, abundant and can be found in all types of habitat but the most in polluted or disturbed habitats.

- Due to their short life cycles (usually about one year) mean fluctuations in water quality are reflected in the population.

- Mainly they are quite immobile and cannot escape pollution.

- Mostly spend their life in water.

- $\quad$ Easily to sample and also easy to identify.

Estimating the abundance and diversity of benthic macrobenthos in an aquatic ecosystem gives a clear indication of the biological conditions (Table 2). It is well known that unpolluted water bodies tend to support an extensive variability of macrobenthos taxa, including several pollution intolerant species, while any polluted water bodies sustenance only pollution-tolerant species and little species diversity. Total suspended solids can subject macrobenthos to abrasion as sediment and push them into the water 
Table 2. Common groups of pollution tolerance freshwater macrobenthos.

\begin{tabular}{lll}
\hline Pollution tolerance & Group & Scientific name \\
\hline Intolerant & Stoneflies & Plecoptera \\
& Caddisflies & Trichoptera \\
& Mayflies & Ephemeroptera \\
Somewhat tolerant & Dragonflies & Odonata - Anisoptera \\
& Damselflies & Odonata - Zygoptera \\
& Freshwater shrimp & Amphipoda \\
& Beetles (True bugs) & Hemiptera \\
& Black flies & Nematocera \\
& Flatworms & Planaria \\
& Alderflies & Megaloptera \\
& Leeches & Hirudinea \\
& Midges & Nematocera \\
& Worms & Oligochaeta \\
\hline
\end{tabular}

column. This results in the damage to exposed respiratory organs or makes the organism more vulnerable to predation over dislodgement (Langer, 1980). A high quantity of suspended solids can choke the feeding structures and decline the feeding efficacy of filter-feeding macrobenthos which reduces the growth rates, amplified stress levels, and even mortality (Hynes, 1970). Several types of research showed that increased in suspended solid levels directly influences the downstream migration of macrobenthos. Sedimentation results in the infilling of the interstitial habitat of the macrobenthos which is crucial for crevice-occupying macrobenthos and also suffocates the benthic fauna by covering their respirational surfaces are probable to result in death.

\section{Impacts of pollutants on survival of fish species}

A high quantity of suspended water pollutants can interrupt the normal behaviour of fish populaces. Various fish species rely on sight to catch their prey quickly e.g. perch, brown trout, etc. are most susceptible to the high quantity of suspended solids and shows very strong avoidance behaviour. In some cases where the fish species survive in turbid water habitat, suspended solids can clog/harm gills aperture and reduced the resistance towards various disease and parasites (EPA, 2012). Fish species may also consume these suspended solids, results in illness by exposing to potential toxins or pathogens on the sediment. If the fish species do not die by consuming the suspended solids it can alter the blood profile and also damage its growth (EPA, 2012). Water pollutants can diminish the egg, embryo by reducing DO. Pollutants interfere various physiological processes without causing certain death. Lethal constituents and suspended dregs covers all the mucous membrane of fish gills which affect the respiration process. Mainly, mercury and lead hinder the activities of digestive enzymes. 
Pollutants effects on a given fish population without being fatal to adult organisms in several ways i.e. (Subhendu, 2000).

- $\quad$ Nutrition and food chain

- Physiological progressions

- Life cycle

- Behaviour

- Incidence of diseases

- Migration.

- $\quad$ Genetic effects

- Breeding and spawning

- Alteration in morphology

\section{Morphological deformities in fish body due to pollutants}

Different types of morphological abnormalities formed on all portions of the fish was reported times to times by researchers (Abel, 2007; 2009; Adams, 2004; Kakulu, 1987; Kumar et al., 2018: Kamboj et al., 2020; Sharma et al., 2018; 2019). These are:

- Scale disorientation

- Split fins

- $\quad$ Fin deformity

- Opercular deformity

- Hyperplasia of the surface of the mouth

- Protruding mouth or nose part depression

- Gill deformity

- Jaw deformity

- $\quad$ Eye deformity

- Muscle atrophy

- Skeleton deformity

- Outward protrusion of the lower lip

- Tumours and other swellings

\section{Effects of pollutants on fish Behaviour}

Pollutants effects directly and indirectly on the behaviour of aquatic organisms (Zala and Penn, 2004; Saaristo et al., 2018), particularly in fish species (Robinson, 2009; Sloman and McNeil, 2012). Inorganic and organic pollutants also effect on various behavioural activities i.e. feeding, sexual and sociability 
aggressiveness behaviours (Table 3). Some pollutants can have caused alterations of the neurotransmitter, hormone levels and cholinesterase activity of fish species (Brodin et al., 2014; Vindas et al., 2017). Pollution-induced variations in behaviours of fishes could potentially increase further the level of exposure to pollutants and result in positive feedback loops which imply the negative impacts of pollution on fish health.

Several types of spatial behaviours i.e. activity, exploration, and avoidance are main behavioural characters that are habitually affected by water pollution. Those aquatic organisms which lead most of their life in metal-polluted regions (e.g. lead and cadmium) with high levels of metal in their blood profile showed slower exploration tendencies (Grunst et al., 2019). Such reduced exploration tendencies have affected the fish ability to assess habitat quality because exploration is the main trait which enable individual to collect information and cues about their surrounding ecosystem (Reader, 2015), also, the interactions within the community are often altered by these contaminants (Ward et al., 2008), which in turns decline the social learning and the gaining of information from their conspecifics (Brown and Laland, 2003). Spatial memory power and learning capacity are deeply impacted by pollutants as in the case of Atlantic salmon where aluminium contamination lessened the learning performance in a maze task and decreases their capability to process information and manage with novel environments (Grassie et al., 2013). Pesticides also distressed certain activities and spatial memory in Danio rerio and Gobiocypris rarus (Hong and Zha, 2019).

Table 3. The linkage among the pollutants and behaviour in fish species.

\begin{tabular}{|c|c|c|c|c|c|c|}
\hline Contaminant & Fish species & Behavioural traits & MS & $\mathrm{S}$ & V & Source \\
\hline Fluoxetine & $\begin{array}{l}\text { Several fish } \\
\text { species }\end{array}$ & $\begin{array}{l}\text { Antipredator } \\
\text { behaviour, } \\
\text { boldness, } \\
\text { aggression, } \\
\text { associative } \\
\text { learning }\end{array}$ & Yes & Yes & No & $\begin{array}{l}\text { Dzieweczynski et al } \\
\text { (2016); } \\
\text { Eisenreich et al. } \\
\text { (2017); } \\
\text { Martin et al. (2017); } \\
\text { Saaristo et al. (2017) }\end{array}$ \\
\hline Oxazepam & Salmo salar & Migration & Yes & No & No & $\begin{array}{l}\text { Hellstrom et al. (2016); } \\
\text { Klaminder et al. (2019) }\end{array}$ \\
\hline $\begin{array}{l}\text { Carbaryl, } \\
\text { chlordane, } \\
\text { 2,4 DMA, DEF, } \\
\text { Methyl parathion, } \\
\text { pentachlorophenol }\end{array}$ & $\begin{array}{l}\text { Oncorhynchus } \\
\text { mykiss }\end{array}$ & Activity, feeding & Yes & No & No & Little et al. (1990) \\
\hline Mercury & Danio rerio & Activity, escape & Yes & No & No & Weber (2006) \\
\hline $\begin{array}{l}\text { Methylmercury } \\
\text { MeHg }\end{array}$ & $\begin{array}{l}\text { Fundulus } \\
\text { heteroclitus }\end{array}$ & Sociality & No & No & Yes & $\begin{array}{l}\text { Ososkov and Weis } \\
\text { (1996) }\end{array}$ \\
\hline
\end{tabular}

MS: multi-stress; S: syndrome; V: variability. 


\section{Water pollution induced histopathological changes in fish organs/tissues}

Histopathology deals with the structure of the body tissue. Any unusual alteration of cells can specify the effect of toxic substances and the presence of various diseases. Abdullah et al. (2008) reported various histological changes in the liver of Tilapia nilotica which was reared in polluted water with heavy metals showing cloudy swelling, vacuolar and hydropic variations of the hepatocytes and also prominent coagulative necrosis. Velcheva et al. (2010) studied the pathological fluctuations in both gills and liver of Alburnus alburnus and Perch from polluted Dame Lake showing deterioration of cytoplasm in hepatocytes, which finally become necrotic and infiltrated with inflammatory cells. Similar scratches were also recorded by (Abdullah et al., 2008) in Tilapia nilotica fish. Recently Ebrahimi and Taherianfard (2011) reported the histopathological variations in liver, kidney and muscles of cyprinids fish species from polluted River Kor where hemosiderosis, melanophages hyperactivation, biliary canaliculi dilatation, and perivascular edema occurred in fish organ and tissue. Also, the skin of Tilapia species was adversely impacted by heavy metals pollution showing hyperactivation of goblet cells and dermal melanosis and dermal granuloma. Similarly, the polluted water kidneys of carp fish showed interstitial nephritis, renal necrosis, and mononuclear cell infiltration Also Brain shows dermal granuloma symptoms of meningitis and gliosis.

\section{Impact of pollutants on fishe liver}

El-Naggar et al. (2009) reported that the liver plays an important role in digestion activity during filtration and for the storage of glucose in all fish species. Tayel et al. (2008) reported that the bile is also produced by the liver which is then stored into the gall bladder. So, the liver of fish is a good indicator of aquatic pollution, because one of the chief functions of the liver is to clean any toxins or pollutants from the bloodstream (El-Naggar et al., 2009). Because the liver is mostly associated with the detoxification and biotransformation progression, it is one of the most affected organs by contaminants in water (Mohamed, 2009). Different types of alterations included necrosis, fibrosis, pyknosis, fatty degeneration, and hemosiderin in hepatocytes are mainly caused by the heavy metal pollution. The liver of both Mugil cephalus and Mugil capito fish showed the same histopathological changes in kidney from lake Manzalah (Kadry et al, 2003). Mohamed, (2001) reported the cellular deterioration in the liver due to oxygen deficiency results the vascular dilation and intravascular hemolysis in the blood vessels with successive stasis of blood. Hepatocyte degeneration and necrosis may be due to the combine effect of nutrients and salts (Authman and Abbas, 2007). Also, the accumulation of hemosiderin in cells of the liver may be due to quick and constant destruction of erythrocytes (Ibrahim and Mahmoud, 2005).

\section{Impact of pollutants on Kidney of fishes}

The kidneys are the important organ of the fish body and play important functions like maintaining the 
homeostasis. The removal of wastes from the bloodstream, selective reabsorption activities, upholding volume, and maintaining the $\mathrm{pH}$ of blood and body fluid are done by the kidneys (Iqbal et al., 2004). Thophon et al. (2003) reported in his research, that the kidney was one of the first organs to be affected by contaminants in the polluted water. The kidney of Mugil cephalus and Mugil capito from Manzalah lake showed the histopathological changes with diverse degrees of severity (Kadry et al, 2003). Mahmoud et al. (2008) reported that industrial, agricultural, and sewage wastes caused renal injury in the kidney of fish species dwelling in different regions of the Nile river. Similar results were observed in C. carpio species exposed to sewage waste (Kakutta and Murachi, 1997). Many necrotic scattered all over the hematopoietic tissue and renal tubules of the rainbow trout were observed by (Capkin et al., 2006) due to alteration in the quality of water like rising in $\mathrm{pH}$ level, temperature, hardness, etc. Kadry et al. (2003) reported some injuries in the kidney tissue of Liza Ramada fish obtained from polluted water in Manzalah lake. These injured kidneys showed degeneration of renal tubules and distortion of glomerular capillaries.

\section{Effects on pollutants on fish eggs, spawn, fry and fingerlings}

Generally, the eggs of fish species are much more resistant as compared to the adult fish species. Normally, Eggs are developed within between $\mathrm{pH} 6$ to 9. The eggs displayed exosmosis and even collapsed in that water body where the acid is more than $\mathrm{pH} 4.0$ Similarly in other conditions where water is more alkaline than $\mathrm{pH} 9.0$ showed endosmosis along with the swelled eggs and also yolk became white. The critical value of the oxygen tensions for newly fertilized eggs is about $40 \mathrm{~mm} \mathrm{Hg}$ and rises at the time of embryo development to about $100 \mathrm{mg} \mathrm{Hg}$ (60\% saturation) at the time of hatching. Salmon and Trout fish species commonly lay their eggs in gravel-bed through which water must infiltrate while the eggs and the fry live the yolk of the eggs (Adams and Onorato, 2005).

\section{Conclusion}

Different types of impurities and toxins enter into the aquatic ecosystem and impact the water quality and disturb the life cycle of aquatic organisms. Some pollutants are very active to damage the aquatic organisms both morphologically and metabolically. Nevertheless, there is only inadequate evidence that water impurities and pollutants are truly accountable for the expansion of disease in aquatic animals. The revelation of aquatic animals to pollutants for the long term caused the ceaseless risk of health. So, directly and indirectly, aquatic animals are at higher risk due to various anthropogenic activities. For these problems, it is very clear that everyone should take the essential pre-emptive measure to guard the aquatic communities. Diverse effect of pollutants on the population of various fish species has been reported by a number of researcher's time to time and predict a chronic level which causes different effects on the aquatic life i.e. changes in histopathological, physiological 
damages, migration, embryonic and developmental changes especially in fish species. Several pollutants in the atmosphere constituted of various toxicant compound i.e. organophosphate compounds bring lethal effects in fish species. Thus, to overcome these problems it is important to develop some approaches using molecular biology techniques that will modernize toxicological bids that are low-priced and do not demand the aquatic animals to detect ecological stressors. More research struggles must be done to establish the concentration level and exposure time of all the pollutants and also it is very important to persuade significant lethal and sub-lethal effects on the aquatic organism.

Conflict of interest: The author declares that there is no conflict of interest.

\section{Acknowledgment}

The authors are thankful to Department of Zoology and Environmental Science, Gurukula Kangri (Deemed to be University), Haridwar, (Uttarakhand) for providing all necessary facilities during the study.

\section{References}

Abdullah, A., Mehana, E.E. and Meki, A. (2008). Evaluation of lead and cadmium levels in freshwater fish farms at Qassim region, KSA. Journal of Agricultural and Veterinary Sciences, 1(2): 59-69.

Abel, O.A. (2009). An analysis of solid waste generation in a traditional African city: the example of Ogbomoso, Nigeria. Environment and Urbanization, 19: 527-537.

Abel, O.A. and Afolabi, O. (2007). Estimating the quantity of solid waste generation in Oyo, Nigeria. Waste Management and Research, 25: 371-379.

Adams, D.H and Onorato, G.V. (2005). Mercury concentrations in red drum, Sciaenops ocellatus, from estuarine and offshore waters of Florida. Marine Pollution Bulletin, 50: 291-300.

Adams, D.H. (2004). Total mercury levels in tunas from offshore waters of the Florida Atlantic coast. Marine Pollution Bulletin, 49: 659-663.

Aich, A., Goswami, A.R., Roy, U.S. and Mukhopadhyay, S.K. (2015). Ecotoxicological assessment of tannery effluent using guppy fish (Poecilia reticulata) as an experimental model: a biomarker study. Journal of Toxicology and Environmental Health, Part A, 78: 278-286.

Ali, F.K., El-Shehawi, A.M. and Seehy, M.A. (2008). Micronucleus test in fish genome: A sensitive monitor for aquatic pollution. African Journal of Biotechnology, 7: 606-612.

Alrumman, S.A., El-kott, A.F. and Kehsk, M.A. (2016). Water pollution: Source and treatment. American Journal of Environmental Engineering, 6(3): 88-98.

Authman, M. and Abbas, H. (2007). Accumulation and distribution of copper and zinc in both water and some vital tissues of two fish species (Tilapia zillii and Mugil cephalus) of Lake Qarun Fayoum Province, Egypt. Pakistan Journal of Biological Sciences, 10: 2106- 2122.

Briggs, D. (2003). Environmental pollution and the global burden of disease. British Medical Bulletin, 68: 1-24.

Brodin, T., Piovano, S., Fick, J., Klaminder, J., Heynen, M. and Jonsson, M. (2014). Ecological effects of pharmaceuticals in aquatic systems impacts through behavioural alterations. Philosophical Transactions of the Royal Society B, 369: 20130580. 
Brown, C. and Laland, K.N. (2003). Social learning in fishes: a review. Fish and Fisheries, 4: 280-288.

Bukola, D., Zaid, A., Olalekan, E.I. and Falilu, A. (2015). Consequences of Anthropogenic Activities on Fish and the Aquatic Environment. Poultry, Fisheries \& Wildlife Sciences, 3(2): 1-12.

Byrne, S., Miller, P., Waghiyi, V., Buck, C.L., von Hippel, F.A. and Carpenter, D.O. (2015). Persistent organochlorine pesticide exposure related to a formerly used defence site on St. Lawrence Island, Alaska: Data from sentinel fish and human sera. Journal of Toxicology and Environmental Health, Part A, 78: 976-992.

Capkin, E., Allinok, I. and Karahan, S. (2006). Water quality and fish size affect toxicity of endosulfan an organochlorine pesticide to rainbow trout. Chemosphere, 64: 1793-1800.

Dzieweczynski, T.L., Kane, J.L., Campbell, B.A. and Lavin, L.E. (2016). Fluoxetine exposure impacts boldness in female Siamese fighting fish, Betta splendens. Ecotoxicology, 25: 69-79.

Ebrahimi, M. and Taherianfard, M. (2011). The effect of heavy metals exposure on reproductive system of cyprinid fish from Kor river. Iranian Journal of Fisheries Science, 10(1): 13-24.

Edokpayi, C.A. and Nkwoji, J.A. (2000). Annual changes in the physico-chemical and microbenthic invertebrate characteristics of the Lagos lagoon sewage dump site at Iddo, Southern Nigeria. Ecology, Environment and Conservation, 13: 13-18.

Eisenreich, B.R., Greene, S. and Szalda-Petree, A. (2017). Of fish and mirrors: Fluoxetine disrupts aggression and learning for social rewards. Physiology of Behaviour, 173: 258-262.

El-Naggar, A.M; Mahmoud, S.A. and Tayel, S.I. (2009). Bioaccumulation of some heavy metals and histopathological alterations in liver of Oreochromis niloticus in relation to water quality at different localities along the river Nile, Egypt. World Journal of Fish and Marine Sciences, 1(2): 105-114.

EPA. (2012). What are suspended and bedded sediments (SABS)? in water: WARSSS. Retrieved from http://water.epa.gov/ scitech/datait/tools/warsss/sabs.cfm.

Farkas, A., Salanki, J. and Varanka, I. (2000). Heavy metal concentrations in fish of Lake Balaton. Lakes and Reservoirs. Reservoir Management, 5: 271-279.

Grassie, C., Braithwaite, V.A., Nilsson, J., Nilsen, T.O., Teien, H.C., Handeland, S.O., Stefansson, S.O., Tronci, V., Gorissen, M., Flik, G. and Ebbesson, L.O.E. (2013). Aluminium exposure impacts brain plasticity and behaviour in Atlantic salmon (Salmo salar). Journal of Experimental Biology, 216: 3148-3155.

Grunst, A.S., Grunst, M.L., Daem, N., Pinxten, R., Bervoets, L. and Eens, M. (2019). An important personality trait varies with blood and plumage metal concentrations in a free-living songbird. Environment Science of Technology, 53: 10487-10496.

Haslam, S.M. (1987). River plants of Western Europe. Cambridge: Cambridge University Press.

Hawkes, H.A. (1962). Biological aspects of river pollution. In: Klein, L. (ed.) River pollution II. Causes and effects. London: Butterworths. pp. 311-432.

Hellstrom, G., Klaminder, J., Finn, F., Persson, L., Alanara, A., Jonsson, M., Fick, J., Brodin, T. (2016). GABAergic anxiolytic drug in water increases migration behaviour in salmon. Nature Communication, 7: 13460.

Hinton, D.E. and Lauren, D.J. (1990). Liver structural alterations accompanying chronic toxicity in fishes. Potential biomarkers of exposure. In: Biomarkers of Environmental Contamination, pp. 17-57.

Hynes, H.B.N. (1960). The ecology of running waters. Liverpool: Liverpool University Press.

Hynes, H.B.N. (1970) The biology of polluted waters. Liverpool: Liverpool University Press.

Ibrahim, S.A. and Mahmoud, S.A. (2007). Effect of heavy metals accumulation on enzyme activity and histology in liver of some Nile fish in Egyptian. Journal of Aquatic Biology and Fisheries, 9(1): 203-219.

Iqbal, Qureshi, F.T.Z. and Ali, M. (2004). Histopathological changes in the kidney of common carp, Cyprinus carpio following nitrate exposure. Journal of Research (Science), 15: 411-418.

Kadry, S.M., Yacoub, A.M., Siliem, T.A. and Mabrouk, D.B. (2003). Injuries in Kidney Tissue of the Mugil fish Liza Ramada as 
a Biomarker for Environmental Pollution in the Lake Manzalah. Egyptian Journal of Aquatic Biology and Fisheries, 7(3): 124.

Kakulu, S.O., Osibanjo, O. and Ajayi, S.O. (1987). Trace Metal Content of Fish and Shellfishes of the River Niger Delta Areas of Nigeria. Environment International, 13: 247-251.

Kakute, I. and Murachi, S. (1997). Physiological response of carp, Cyprinus carpio, exposed to raw sewage containing fish processing waste waters. Ed. John Wiley and sons, Inc. Environ. Toxicology water Quality, pp. 12: 1-9.

Kamboj, N., Kamboj, V. and Sharma, A.K. (2020). Length-Weight relationships of selected fish species at mining bed stretch of river Ganga at Haridwar. Annals of Agri-Bio Research, 25(2): 251-254.

Kamboj, V., Kamboj, N. and Sharma, A.K. (2020). A review on general characteristics, classification and degradation of river systems, in: Environmental Degradation: Causes and Remediation, Volume 1, Eds, Kumar, V., Singh, J. and Kumar, P. (eds.), pp. 47-62.

Kaur, R. and Dua, A. (2015). Scales of freshwater fish Labeo rohita as bioindicators of water pollution in Tung Dhab Drain, Amritsar, Punjab, India. Journal of Toxicology and Environmental Health, Part A, 78: 388-396.

Khoshnood, Z. (2016). Using Biomarkers in Ecotoxicology: What and Why? Focus on Sciences, 2(2): 1-2.

Khoshnood, Z. (2017). Effects of Environmental Pollution on Fish: A Short Review. Transylvanian Review of Systematical and Ecological Research, 19: 1-10.

Klaminder, J., Jonsson, M., Leander, J., Fahlman, J., Brodin, T., Fick, J. and Hellstrom, G. (2019). Less anxious salmon smolt become easy prey during downstream migration. Science of the Total Environment, 687: 488-493.

Kumar, D., Malik, D.S., Sharma, A.K. and Gupta, V. (2019). Estimation of Length-weight and Length-length Relationship of Catfish, Rita rita Inhabiting in the Middle Stretch of River Ganga. Annals of Biology, 35(2): 156-159.

Kumar, V., Malik, D.S. and Sharma, A.K. (2018). Study on Distribution Pattern of Benthic Diversity in Relation to Water Quality of River Ganga And Its Tributaries. Journal of Emerging Technologies and Innovative Research, 5(5): 88-103.

Langer, O.E. (1980). Effects of sedimentation on salmonid stream life. In: Weagle, K. (ed.), Report on the Technical Workshop on Suspended Solids and the Aquatic Environment. Yukon Territory: Whitehorse.

Little, E.E., Archeski, R.D., Flerov, B.A. and Kozlovskaya, V.I. (1990). Behavioural indicators of sublethal toxicity in rainbow trout. Archives of Environmental Contamination and Toxicology, 19: 380-385.

Liu, X., Lu, S., Guo, W., Xi, B. and Wang, W. (2018). Antibiotics in the aquatic environments: A review of lakes, China. Science of the Total Environment, 627: 1195-1208.

Mahmoud, S.A., Tayel, S.I. and Yacoub, A.M. (2008). Histopathological changes in kidneys of the fish Tilapia zillii and Clarias gariepinus under the effect of several pollutants along the River Nile, Journal of the Egyptian German Society of Zoology, 56 (C): 219-246.

Malik, D.S., Sharma, A.K. and Sharma, A.K. (2020). Current Status of Microbenthic Diversity And their Habitat Ecology in River Ganga and its Tributaries, Uttarakhand India. Journal of Experimental Zoology, 23(2): 1413-1420.

Malik, D.S., Sharma, A.K. and Bargali, H. (2018). Status of phytoplankton diversity in relation to water quality of Bhagirathi riverine system in Garhwal Himalaya. International Journal of Advanced Science and Research, 3(1): 30-37.

Martin, J.M., Saaristo, M., Bertram, MG., Lewis, P. J., Coggan, T.L., Clarke, B.O., Wong B. B.M. (2017). The psychoactive pollutant fluoxetine compromises antipredator behaviour in fish. Environmental Pollution, 222: 592-599.

Mason, C.F. (1991). Biology of freshwater pollution, 2nd edition. Harlow: Longman Scientific and Technical.

Maurya, P.K., Malik, D.S. and Sharma, A.K. (2019). Impacts of pesticides application on aquatic environments and fish diversity. In: Kumar, V., Kumar R., Singh, J. and Kumar, P. (eds) Contaminants in Agriculture and Environment: Health Risks and Remediation, Volume 1, Agro Environ Media, Haridwar, India, pp. 111-128.

Meijide, F.J., Da Cuna, R.H., Prieto, J.P., Dorelle, L.S., Babay, P.A. and Lo Nostro, F.L. (2018). Effects of waterborne exposure to the antidepressant fluoxetine on swimming, shoaling and anxiety behaviours of the mosquitofish Gambusia 
holbrooki. Ecotoxicology and Environmental Safety, 163:646-655.

Mohamed, F.A. (2001). Impacts of environmental pollution in the southern region of Lake Manzalah, Egypt, on the histological structures of the liver and intestine of Oreochromis niloticus and Tilapia zillii. Journal of the Egyptian Academy of Environmental Development, 2: 25-42.

Mohamed, F.A.S. (2009). Histopathological studies on Tilapia zillii and Solea vulgaris from lake Qarun Egypt. World Journal of Fish and Marine Sciences, 1(1): 29-39.

Nkwoji, J.A., Yakub, A., Ajani, G.E., Balogun, K.J., Renner, K.O., Igbo, J.K., Ariyo, A.A. and Bello, B.O. (2010). Seasonal variations in the water chemistry and benthic macroinvertebrates of a South Western Lagoon, Lagos, Nigeria. Journal of Animal Science, 6: 85-92.

Ososkov, I. and Weis, J.S. (1996). Development of social behaviour in larval mummichogs after embryonic exposure to methylmercury. Transactions of the American Fisheries Society, 125: 983-987.

Pinto, M.F., Louro, H., Costa, P.M., Caeiro, S. and Silva, M.J. (2015). Exploring the potential interference of estuarine sediment contaminants with the DNA repair capacity of human hepatoma cells. Journal of Toxicology Environment and Health A, 78: 559-570.

Plenty, S.J. and Aldous, P. (2018). Freshwater Pollution: Ecological Impact Assessment and Remediation. Foundation for Water Research Allen House, The Listons, Liston Road, Marlow, pp. 40.

Priyadarshi, S. (2020). https://www.biologydiscussion.com/speech/speech-on-water pollution-sources-and-controlmethods/5492.

Qiu, X., Zhu, T., Li, J., Pan, Li Q., Miao, G. and Gong, J. (2004). Organochlorine pesticides in the air around the Taihu Lake, China. Environmental Science and Technology, 38: 1368-1374.

Reader, S.M. (2015). Causes of individual differences in animal exploration and search. Topics in Cognitive Science, 7: 451-468.

Richardson, J., Erica, K., Williams, E.K. and Hickey, C.W. (2001). Avoidance behaviour of freshwater fish and shrimp exposed to ammonia and low dissolved oxygen separately and in combination. New Zealand Journal of Marine and Freshwater Research, 35: 625- 633.

Robinson, P.D. (2009). Behavioural toxicity of organic chemical contaminants in fish: application to ecological risk assessments (ERAs). Canadian Journal of Fisheries and Aquatic Science, 66: 1179-1188.

Saaristo, M., Brodin, T., Balshine, S., Bertram, M.G., Brooks, B.W., Ehlman, S.M., McCallum, E.S., Andrew, S., Sundin, J., Bob, B., Wong, M. and Arnold K.E. (2018). Direct and indirect effects of chemical contaminants on the behaviour, ecology and evolution of wildlife. Proceeding B, 285: 20181297.

Saaristo, M., McLennan, A., Johnstone, C.P., Clarke, B.O. and Wong, B.B.M. (2017). Impacts of the antidepressant fluoxetine on the anti-predator behaviours of wild guppies (Poecilia reticulata). Aquatic Toxicology, 183: 38-45.

Schmeller, D.S., Loyau, A., Bao, K., Brack, W., Chatzinotas, A., De Vleeschouwer, F., Vredenburg, V.T. (2018). People, pollution and pathogens - Global change impacts in mountain freshwater ecosystems. Science of the Total Environment, 622: 756-763.

Sharma, A.K., Malik, D.S. and Bargali, H. (2018). Present status of fish diversity and population abundance of selected fish species in Bhagirathi river at Uttarakhand. International Journal of Creative Research Thoughts, 6(1): 432-438.

Sharma, A.K., Malik, D.S. and Tyagi, D. (2019). Food and feeding habits of Tor tor (Hamilton, 1822) and Schizothorox richordsonii (Gray, 1832) inhibiting Bhagirathi river, Tehri Garhwal, India. International Journal of Science and Nature, 10(1): 97-103.

Sharma, A.K., Malik., D.S. and Bargali, H. (2018). Food and Feeding Habits of Schizothorox Richordsonii (Gray, 1832) Inhibiting Bhagirathi River, Tehri Garhwal, India., International Journal of Recent Scientific Research, 9(4): 25562-25565.

Sloman, K.A. and McNeil, P.L. (2012). Using physiology and behaviour to understand the responses of fish early life stages to toxicants. Journal Fish Biology, 81: 2175-2198.

Subhendu, D. (2000). Effects of aquatic pollution on fish and fisheries. Pollution- An International problem for fisheries. 
Canadian Journal of Fisheries and Aquatic Sciences, 66: 400-480.

Tayel, S.I., Yacoub, A.M. and Mahmoud, S.A. (2008). Histopathological and haematological responses to freshwater pollution in the Nile catfish Clarias gariepinus. Journal of the Egyptian Academy of Environmental Development, 9(4): 43- 60.

Thophon, S.M., Kruatrachuc, E., Upathau, P., Pokcthitiyook, Sahaphong, S. and Javikhuan, S. (2003). Histopathological alterations of white Sea bass, Lates calcarifer in acute and subchronic cadmium exposure. Environmental Pollution, 121: 307-320.

Velcheva, E., Tomova, D., Arnaudova, D. and Arnaudov, A. (2010). Morphological investigation on gills and liver of fresh water fish from Dam Lake "Studen Kladenets". Bulgarian Journal of Agriculture Sciences, 16(3): 364-368,

Ventura, B.C., Angelis, D.F., Maria, A.M. and Morales, M. (2008). Mutagenic and genotoxic effects of the Atrazine herbicide in Oreochromis niloticus (Perciformes, Cichlidae) detected by the micronuclei test and the comet assay. Pesticide Biochemistry and Physiology, 90: 42-51.

Vindas, M.A., Gorissen, M., Höglund, E., Flik, G., Tronci, V., Damsgard, B., Thornqvist, P. O., Nilsen, T.O., Winberg, S., Overli, O. and Ebbesson, L.O.E. (2017). How do individuals cope with stress? Behavioural, physiological and neuronal differences between proactive and reactive coping styles in fish. Journal of Experimental Biology, 220: 1524-1532.

Walia, G.K., Handa, D., Kaur, H. and Kalotra, R. (2015). Ecotoxicological studies on fish, Labeo rohita exposed to tannery industry effluent by using micronucleus test. Nucleus, 58: 111-116.

Ward, A.J.W., Duff, A.J., Horsfall, J.S. and Currie, S. (2008). Scents and scentsability: pollution disrupts chemical social recognition and shoaling in fish. Proceedings of the Royal Society B: Biological Sciences, 275: 101-105.

Weber, D.N. (2006). Dose-dependent effects of developmental mercury exposure on C-start escape responses of larval zebrafish Danio rerio. Journal of Fish Biology, 69: 75-94.

Zala, S.M. and Penn, D.J. (2004). Abnormal behaviours induced by chemical pollution: a review of the evidence and new challenges. Animal Behaviour, 68: 649-664.

Zhu, S., Zhang, Z. and Zagar, D. (2018). Mercury transport and fate models in aquatic systems: A review and synthesis. Science of the Total Environment, 639: 538-549.

*****

Cite this chapter as: Malik, D.S., Sharma, A.K., Sharma, A.K., Thakur, R. and Sharma, M. (2020). A review on impact of water pollution on freshwater fish species and their aquatic environment. In: Advances in Environmental Pollution Management: Wastewater Impacts and Treatment Technologies, Volume 1, Eds. Kumar, V., Kamboj, N., Payum, T., Singh, J. and Kumar, P., pp. 10-28, https://doi.org/10.26832/aesa-2020-aepm-02 